\title{
Cultural Conditions Necessary for Optimal Cellulase Yield by Cellulolytic Bacterial Organisms as They Relate to Residual Sugars Released in Broth Medium
}

\author{
Otajevwo, F.D \\ Department of Microbiology \& Biotechnology \\ Western Delta University, Oghara, Nigeria \\ Aluyi, H.S.A \\ Department of Microbiology \\ University of Benin, Benin City, Nigeria
}

Received: July 18, 2010

Accepted: March 1, 2011

doi:10.5539/mas.v5n3p141

\begin{abstract}
A total of 115 samples made up of 42 (36.5\%) rumen fluid, 36 (31.3\%) cowdung and 37 (32.2\%) soil samples were collected with the aid of sterile swab sticks except for rumen fluid samples which were collected by use of stomach tubes inserted into mouths of cows and by suction, liquor was collected into prewarmed thermo flasks under continuous flushing with carbondioxide. Soil samples were collected into sterile universal containers. All samples were obtained from abattoirs situated at three locations in Benin City, Nigeria. Samples were investigated for cellulolytic bacteria by Filter Paper Yeast Mineral broth method. Cellulase production was assayed by Carboxymethyl cellulose submerged broth culture while residual sugar yield and other cellulolytic activities were determined by 3,5 - Dinitrosalicylic acid, Filter Paper, Microcrystalline and Viscometric methods. Cellullolytic bacterial organisms isolated from both soil and rumen fluids were Bacillus subtilis, Clostridium cellobioparum and Clostridium thermocellum. Pseudomonas aeruginosa was isolated from both soil and cowdung samples while Erwinia spp was obtained from both rumen fluid and cowdung samples. Bacillus circulans and Serratia spp were obtained from soil samples only. Clostridium thermocellum and Erwinia spp produced the highest and lowest cellulase yields respectively. All isolates at $40^{\circ} \mathrm{C}$ and $\mathrm{pH} 6$, recorded optimal sugar yields in culture broth of which Clostridium thermocellum recorded the highest. Lowest yields were recorded at $30^{\circ} \mathrm{C}$ and $\mathrm{pH} 3$ although there was significant difference in individual yields $(\mathrm{P}<0.05)$. Clostridium thermocellum recorded optimal cellulolytic activities at $50^{\circ} \mathrm{C}$ and $\mathrm{pH}$ 6. All isolates attained optimal cellulolytic activities at $32.6 \pm 6.2^{\circ} \mathrm{C}$ and $\mathrm{pH} 6.29 \pm 0.9$ with other broth cultural conditions kept constant. Implications of these findings are discussed.
\end{abstract}

Keywords: Cultural, Conditions, Optimal, Cellulase, Bacteria, Sugars, Broth

\section{Introduction}

Cellulase is an inducible enzyme complex involving synergistic action of endoglucanase $\left(C_{x}\right)$, exoglucanase $\left(C_{1}\right)$ and cellobiase $\left(\mathrm{C}_{\mathrm{B}}\right)$ (Zaldivar et al., 2001). The high cost of cellulase production owing to use of pure chemicals in production coupled with low enzyme activities limits its industrial use (Kalra and Banta, 2008). Major impediments to exploiting the commercial potential of cellulases are the yield stability and the cost of cellulase production. Research should therefore be aimed at taking advantage of the commercial potential of existing and new cellulases in nature (Coral et al., 2002).

Both fungi and bacteria have been heavily exploited for their abilities to produce a wide variety of cellulases and hemicellulases. A lot of emphasis has been placed on the use of fungi because of their ability to produce copious amounts of cellulases and hemicellulases which are secreted into broth medium for easy extraction and purification. Besides, fungal enzymes are often less complex than bacterial hydrolases and can therefore be more readily cloned and produced via recombination in a rapidly growing bacterial host such as Escherichia coli (Maki et al., 2009). However, the isolation and characterization of novel glycoside hydrolases from bacteria are now becoming widely exploited mainly because bacteria have a higher growth rate than fungi a property that 
allows for higher recombinant production of enzymes. Bacterial hydrolases are often more complex and are often expressed in multi-enzyme complexes providing increased function and synergy.

Most importantly, thermophilic, psychrophilic, alkaliphilic, acidophilic and halophilic bacteria inhabit a wide variety of environmental and industrial niches that are extremely resistant to environmental stress (Maki et al., 2009). Bacteria also present an attractive potential for the exploitation of cellulases and hemicellulases due to their rapid growth rate, enzyme complexity and extreme habitat variability (Maki et al., 2009).

Beyond free bacterial cellulases, is the opportunity for whole cells in bacterial co-culture and strains with multiple exploitable characteristics to reduce time and cost of current bio-conversion processes (Miranda et al., 2009). Not only can these strains survive the harsh conditions found in the bio-conversion processes, they often produce enzymes that are stable under such extreme conditions. This may increase rates of enzymatic hydrolysis, fermentation and product recovery. As a result, isolation and characterization of cellulase producing bacteria will continue to be an important aspect of biofuel research.

Cellulase of Paenibacillus spp was found to have maximum CMC activity at $60^{\circ} \mathrm{C}, \mathrm{pH}$ 6.5. Due to the promising thermostability and slight acidic tolerance of this enzyme, it has good potential for industrial use in the hydrolysis of soluble cellulose as well as activity on microcrystalline sources of cellulose (Wang et al., 2008). Paenibacillus campinasensis BLII is a thermophilic spore-forming bacterium which was found to grow between 25 and $60^{\circ} \mathrm{C}$ over a wide range of $\mathrm{pH}$. Optimal growth is around neutral $\mathrm{pH}$ at $55^{\circ} \mathrm{C}$. The physiological properties of this strain and the vast number of free glycosyl hydrolases produced, give this strain potential for use in bio-refining industry. (Ko et al ., 2007).

Bacillus subtilis offers a potentially more valuable thermostable enzyme for the bio-refining industry due to extreme heat tolerance. Cultivation of thermophiles offers several advantages such as reducing the risk of contamination and viscosity thus making mixing easier and this leads to a high degree of substrate solubility while reducing the cost of cooling ( $\mathrm{Li}$ et al., 2008). Bacillus agaradhaerens was shown to have increased optimal thermostability from $50-60^{\circ} \mathrm{C}$ and optimal $\mathrm{pH}$ range of $7-9.4$ (Hirasawa et al., 2006). Cellulomonas flavigena enzyme was found to have optimum cellulase and xylanase activities at $\mathrm{pH} 6$ with an optimum temperature at $50^{\circ} \mathrm{C}$ (Perez-Avalos et al., 2008).

Zaldivar et al. (2001) observed that cellulase production by Trichoderma aureoviridae is best if $\mathrm{pH}$ doesn't fall below 3.5 and at an optimum temperature of $28^{\circ} \mathrm{C}$. Pei-Jun et al. (2004) reported a pH of 6.5 for optimum cellulase production by Trichoderma. koningii. Kalra and Banta (2008) reported $\mathrm{pH}$ and temperature of 5 and $30^{\circ} \mathrm{C}$ respectively as optimal for cellulase yield. Cellulolytic endoglucanase activity of Cellulomonas spp, Bacillus spp and Micrococcus spp on coir fibre was optimal at $\mathrm{pH} 7$ and temperature $40^{\circ} \mathrm{C}$ (Immanuel et al., 2006). Some previous studies reported that the agricultural wastes of lignocellulosics are used as carbohydrate source to produce commercially important products such as ethanol, glucose and single cell protein (Solomon et al., 1999).

Carbon source, cellulose quality, $\mathrm{pH}$ value, temperature, presence of inducers, medium additives, aeration and growth time have been reported to be important parameters in optimizing cellulase production (Immanuel et al., 2006) and among these, $\mathrm{pH}$ is of major interest (Judasz et al., 2004).

As a result of the high cost of cellulase production with its low enzyme activities owing to the use of chemicals in its industrial production, efforts are needed to economize cellulase production through media (cultural) optimization and use of supplements and/or additives (Kalra and Banta, 2008). Researches have been carried out and are still ongoing all aimed at isolating potential cellulase producing microorganisms from diverse habitats (Ray et al ., 2007).

Cellulases have uses as/in chemicals, fuels, food, brewery, wine, animal feeds, textile, laundry, pulp/paper and agriculture (Bhat 2000; Sun and Cheng, 2002). It is on record that most African countries such as Nigeria spend foreign exchange to import cellulases. Cellulases can be locally sourced invitro by first screening for cellulolytic bacteria and optimizing their cultural conditions for maximal yield. The technology can then be scaled up by our industries and invariably, government can be helped to save scarce foreign exchange.

Cellulosic wastes will yield free cellulose after delignification. Bacterial cellulases can convert cellulose to reducing sugars which on fermentation, is converted to ethanol - a raw material for methane and biogas production. Ethanol can be dehydrated to obtain ethylene gas. This study is therefore aimed at investigating the cultural conditions necessary for optimal cellulase yield by cellulolytic bacterial organisms as they relate to residual sugars released into broth medium with the following objectives: (1) isolate and screen for bacterial cellulase producers peculiar to the study environment (2) determine sample site distribution of cellulolytic 
organisms (3) determine cellulase production capacity of cellulolytic isolates (4) determine residual sugar production levels of isolates at varying temperature and $\mathrm{pH}$ conditions.

\section{Materials and Methods}

A total of 115 samples made up of 42(36.5\%) rumen fluid, 36(31.3\%) cow dung and 37(32.2\%) soil samples were collected from abattoirs situated at three locations in Benin City, Nigeria. Cowdung samples were collected with sterile swab sticks while soil samples were obtained from the immediate environment of the abattoir littered with cowdung in sterile universal containers. Soil was dug about $20 \mathrm{~cm}$ deep (Okoth et al., 2007) before samples were collected. Rumen samples (taken from recently killed cows) were obtained by use of stomach tubes inserted into the mouths of cows and by suction, liquor was collected into prewarmed thermo flasks under continuous flushing with carbondioxide. All collected and well labeled samples were taken to the laboratory for immediate processing.

Cow dung samples were processed by dipping the swab end of each stick into $5 \mathrm{ml}$ sterile distilled water (after breaking off the stick). This set up was shaken and using sterile pasteur pipettes (with intermittent rinsing in sterile water), two drops $(0.04 \mathrm{ml})$ of resulting suspension were streaked on carboxymethyl cellulose agar medium described by Bassey (2002).

Soil samples were collected into $20 \mathrm{ml}$ sterile plastic universal containers from which soil suspensions were made. Twenty grams $(20 \mathrm{~g})$ of each soil sample was weighed out and dissolved in $50 \mathrm{ml}$ of sterile water in sterile screw capped $100 \mathrm{ml}$ bottles. This was properly mixed and using sterile glass pipettes, two drops $(0.04 \mathrm{ml})$ of resulting suspension of each sample were streaked on sterile carboxymethyl cellulose agar medium as described by Bassey (2002).

The composition of the medium described by Bassey (2002) per litre (1000ml sterile water) is: Cellulose powder (8.0g), Agar - agar (30.0g), $\mathrm{K}_{2} \mathrm{HPO}_{4}(1.65 \mathrm{~g}),\left(\mathrm{NH}_{4}\right)_{2} \mathrm{SO}_{4}(1.60 \mathrm{~g})$, Yeast extract $(1.0 \mathrm{~g})$, Cysterine $(0.5 \mathrm{~g}), \mathrm{CaCl}_{2}$ $(0.096 \mathrm{~g}), \mathrm{MgSO}_{4}(0.096 \mathrm{~g}), 0.1 \%$ Resazurin $(0.1 \mathrm{ml}), \mathrm{pH} 7.2$. The $\mathrm{pH} 7.2$ was maintained by dropwise addition of $5 \mathrm{M} \mathrm{NaOH}$.

Agar - agar powder together with the cellulose powder (carboxymethyl cellulose) was gradually dissolved in $200 \mathrm{ml}$ distilled water first and made up to $500 \mathrm{ml}$. A paste suspension was obtained (A). The other constituents were first dissolved in $200 \mathrm{ml}$ distilled water and made up to $500 \mathrm{ml}$ (B). A and B were then mixed together and mixture was distributed into $2(500 \mathrm{ml})$ screw capped bottles and autoclaved at $121^{\circ} \mathrm{C}$ for 15 minutes. Molten medium was allowed to cool to $45^{\circ} \mathrm{C}$ and 2 tablets of griseofulvin were dissolved into the molten agar asceptically i.e. 1 tablet $(500 \mathrm{mg})$ dissolved in $500 \mathrm{ml}$ molten agar. This was to prevent fungal contamination of medium. The preparation was dispensed into sterile glass petri dishes (in $2 \mathrm{ml}$ volumes) on sterilized laboratory bench. Surface of poured plates were bunsen flamed to remove air bubbles and plates were left to set.

The above medium (before pouring into plates) was modified by addition of thioglycollate powder (Biotec, UK) for isolation of strict anaerobes. The original medium was used to isolate facultative and strict aerobes. The original media (liquid and solid) were carboxymethyl cellulose mineral nutrient medium (CMCM nutrient medium) and carboxymethyl cellulose mineral agar medium (CMCMA medium). Whereas the former did not contain agar, the latter did. The modified media (liquid and solid) were: Thioglycollate carboxymethyl cellulose mineral liquid medium (TCMCM nutrient medium) and Thioglycollate carboxymethyl cellulose mineral agar medium (TCMCMA medium)

Processed rumen fluid, cow dung and soils samples were inoculated into sterile TCMCM and CMCM Liquid media screw capped bottles and incubated at $37^{\circ} \mathrm{C}$ for 24 hours. Whereas TCMCM was used to grow strict (obligate) anaerobes, $\mathrm{CMCM}$ medium was used to grow strict aerobes, facultative aerobes and anaerobes. Bottles that showed turbidity (cloudiness) were subcultured onto their corresponding solid media agar plates. Positive CMCM bottles were subcultured on CMCMA plates and incubated at $37^{\circ} \mathrm{C}$ for 24 hours while positive TCMCM plates were subcultured on TCMCMA plates and incubated inside anaerobic jar (Mackintosh \& Fildes jar) at $37^{\circ} \mathrm{C}$ for 24 hours.

\section{Preservation of Isolates/Bacterial Suspension Preparation}

Pure cultures of bacterial isolates were obtained and preserved on CMCA slants by subculturing from CMCMA plates onto the slants aseptically and incubating at $37^{\circ} \mathrm{C}$ overnight. The resulting stock cultures were kept in the refrigerator at $4^{0} \mathrm{C}$ for further use. Anaerobic isolates on TCMCMA plates were immediately scrapped into TCMC broth containing heated iron fillings to obtain bacterial suspension. Bacterial suspensions of aerobic isolates were also prepared by scrapping surface of CMCA stock (slant) cultures into sterile CMC broth submerged culture in sterile $100 \mathrm{ml}$ screw capped bottles and bottles were shaken to mix. 


\section{Screening for Cellulolytic Bacterial}

The Filter Paper Yeast Mineral Salts (FPYM) broth method by Dhawan and Gupta (1997) was used. This assay was used to separate cellulase producers from non- cellulase producing isolates.

One thousand milliliters $(1000 \mathrm{ml})$ of the prepared sterile FPYM broth medium was distributed in $50 \mathrm{ml}$ volumes into $500 \mathrm{ml}$ flasks and $15 \mathrm{~cm}$ diameter whatman filter paper No. 1 was folded into a cone and placed inside each flask with the apex up. All flasks were properly stoppered with cotton wool and sealed with aluminum foil paper and autoclaved at $121^{\circ} \mathrm{C}$ for 15 minutes. All flasks were allowed to cool and labeled appropriately. One milliliter $(1 \mathrm{ml})$ of the bacterial suspension of each isolate was aseptically dispensed into each flask. All inoculated and labeled flasks were incubated at $37^{\circ} \mathrm{C}$ for 24 hours. Positive flasks (i.e. those with yellow and brown mottling/disintegration of filter paper were noted. Positive organisms which were cellulase producers were then identified and characterized.

\section{Identification of Cellulolytic Bacterial Organisms}

The identification and characterization of the cellulolytic bacterial organisms were carried out according to the methods of Cullimoore (2000) and Cowan and Steel (1993). The characteristics considered included cultural, morphological, biochemical tests as well as sugar fermentation tests. The cultural characteristics observed were: colour, optical density, pigmentation, margin, elevation and forms of colonies. The morphological features revealed by gram stain included cell shapes and sizes. The following biochemical tests: motility, indole production, citrate utilization, urease, oxidase, methyl red, voges proskauer, $\mathrm{H}_{2} \mathrm{~S}$ production, beta galatosidase, phenylalanine deaminase and fermentation tests were carried out and the following cellulase producing bacterial organisms were identified accordingly:

Large, irregular spreading colonies on TCMCMA plates, gram positive rod shaped cells with swelling endospores occurring in singles, motile, lactose/sucrose fermenting (with acid and gas), cellulose fermenting (with acid) colonies which grew weakly on nutrient Agar - characteristic of Clostridium cellobioparum, (2) Large, irregular, spreading colonies on TCMCMA plates, gram positive bacilli with round central or terminal endospores, motile, lactose fermenting (with acid and gas), sucrose negative, cellulose fermenting (with acid and gas) colonies - characteristic of Clostridium thermocellum (3) Orange, bead like colonies with convex elevation, gram negative short rods occurring in chains with hollow centre, motile, voges proskauer positive, beta galactosidase positive, gelatin liquefaction positive, lactose, mannitol and cellulose fermenting (with acid only) colonies which only grow on media containing cellulose - characteristics of Serratia spp.

The others were: (4) Light brown, flat colonies with irregular edges and spreading rapidly on the surface of agar medium, gram positive bacilli in singles with spores centrally positioned, motile, oxidase positive, glucose fermenting (with acetoin and gas), cellulose fermenting (with acid and gas) and non sucrose fermenting characteristic of Bacillus subtilis. (5) Light brown, flat colonies with irregular edges and spreading rapidly on the surface of agar medium, gram positive bacilli in singles with spores terminally positioned, non-motile, oxidase negative, non lactose fermenting, non mannitol fermenting, glucose fermenting (with acid and gas), cellulose fermenting (with acid only) and fructose fermenting (with acid and gas) colonies - characteristic of Pseudomonas aeruginosa. (7) Smooth, raised motile colonies, gram negative short bacilli in singles and short chains, voges proskauer positive beta galactosidase positive, lactose, glucose, mannitol fermenting ( with acid gas) and cellulose fermenting (with acid only) - characteristics of Erwinis spp.

\section{Cellulase Enzyme Production}

For enzyme studies, CMCM and TCMCM broths were used to carry out cellulase production by both cellulolytic aerobes and anaerobes so identified. Broths were prepared by dissolving the mineral salts (as previously described) in sterile $1000 \mathrm{ml}$ distilled water and mixture was dispensed in $50 \mathrm{ml}$ volumes into sterile $100 \mathrm{ml}$ screw capped bottles (the number of bottles equivalent to the number of isolates). Following that, $0.5 \mathrm{~g}$ of carboxymethyl cellulose powder (Biotec, UK) was added to the content of each bottle and shaken properly, screwed leaving little space. All bottles were autoclaved at $121^{\circ} \mathrm{C}$ for $15 \mathrm{mins}$ and allowed to cool after bottles were tightly screwed. All bottles were properly labeled. Five milliliters $(5 \mathrm{ml})$ of bacterial suspension of both aerobes and anaerobes as previously described), was inoculated aseptically into each broth as labeled. A sterile CMCM broth (without any inoculation) and a sterile TCMCM broth (without any inoculation) were set up as controls for aerobes and anaerobes respectively.

All inoculated bottles were incubated at $37^{\circ} \mathrm{C}$ for 24 hours. At the end of incubation, $10 \mathrm{ml}$ of submerged broth culture of each isolate was collected into sterile centrifuge tubes and spun for 15 minutes. Same treatment was done on controls and labeled as such. The supernatant containing the crude enzyme solution) was then partially purified according to the Acetone method of Okolo (2004). The partially purified enzyme solutions were then characterized by assaying for reducing sugars by DNS method of Miller (1972), $\mathrm{C}_{1}$ (exoglucanase) activity by 
filter paper method of Somogyi (1977), Cx (endoglucanase) activity by Mackenzie (1987), extracellular protein content by Lowry et al. (1951) and percentage loss of viscosity by Norkrans \& Hammarstron (1963). Controls were treated as tests and all results recorded.

\section{Reducing Sugars Assays by DNS Method}

The amount of reducing sugars released by the cellulolytic bacterial organisms was determined by the Dinitrosalicylic Acid (DNS) method of Miller (1972). The 3, 5 dinitrosalicylic acid in hot alkaline solution (when boiled for 5minutes) is reduced to 3 amino, 5 - nitrosalicylic acid which possesses a deep orange colour and determined spectrophotometrically. The DNS reagent solution was prepared by first dissolving $10 \mathrm{~g} \mathrm{NaOH}$ and $200 \mathrm{~g}$ of sodium potassium tartrate (Rochelle's salt) in one litre of distilled water before the addition of $2 \mathrm{~g}$ phenol and $10 \mathrm{~g}$ DNS reagent in that order. The DNS solution was warmed for complete dissolution. Glucose $(0.07 \% \mathrm{w} / \mathrm{v})$ and sodium sulphite $(5 \% \mathrm{w} / \mathrm{v})$ solution were prepared separately and $1 \mathrm{ml}$ of each was added to $100 \mathrm{ml}$ of the DNS solution before use. The DNS solution was stored in a brown bottle and kept at $4{ }^{0} \mathrm{C}$ in a refrigerator.

To prepare a standard Glucose Calibration (of absorbance versus glucose concentrations), $1 \mathrm{~g}$ of D - glucose (sigma) was dissolved in $1000 \mathrm{ml}$ of distilled water and mixed properly. The mixture was serially diluted to give $0.1,0.2,0.3,0.4,0.5,0.6,0.7,0.8,0.9$ and $1 \mathrm{mg} / \mathrm{ml}$ of distilled water. Each standard glucose dilution was then treated by making a further half dilution with sodium citrate/citric acid buffer prepared according to the method described by Srinivasan (1997). One milliliter $(1 \mathrm{ml})$ of the buffer was added to $1 \mathrm{ml}$ of each glucose standard dilution as prepared earlier. Three milliliters $(3 \mathrm{ml})$ of DNS solution was added and mixture was immersed in boiling water for 5minutes, cooled and absorbance read at 540nm using the spectronic - N21 spectrophotometer.

A standard glucose curve of optimal density (absorbance) against glucose concentrations was plotted to obtain a standard calibration curve from which the sugar concentrations of unknown samples (test samples) were extrapolated using their respective absorbances (obtained by treating test samples as the diluted D - glucose concentrations).

\section{Effect of pH Changes on Enzyme Yield in Submerged Culture}

The components of the cellulose nutrient medium were weighed without the phosphate (i.e. $\mathrm{K}_{2} \mathrm{HPO}_{4}, \mathrm{KH}_{2} \mathrm{PO}_{4}$ )

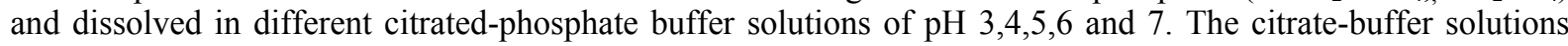
were prepared on the basis of the data complied by Munro (1970). The first step was the preparation of stock solutions of $0.1 \mathrm{~m}$ citric acid and $0.2 \mathrm{M}$ dibasic sodium phosphate. Citric acid was prepared by dissolving $19.21 \mathrm{~g}$ of the acid in $1000 \mathrm{ml}$ of distilled water. The other was prepared by dissolving $71.7 \mathrm{~g} \mathrm{Na}_{2} \mathrm{HPO}_{4} .12 \mathrm{H}_{2} \mathrm{O}$ in $1000 \mathrm{ml}$ of distilled water.

All the broths were sterilized and allowed to cool. They were labeled and each bacterial suspension (as labeled) and prepared earlier was inoculated (in $5 \mathrm{ml}$ volume) into the broth. Anaerobisis was maintained for Clostridium cellobioparum and Clostridium thermocellum by introducing heated iron fillings into the broths before inoculation. Broths were incubated at $37^{\circ} \mathrm{C}$ for 24 hours after which, residual sugars, protein content, $\mathrm{C}_{1}, \mathrm{C}_{\mathrm{x}}$ and percentage loss of viscosity of carboxymethyl cellulose were determine and recorded.

\section{Effect of Temperature Changes on Enzyme Yield in submerged culture}

Identified cellulolytic bacterial organisms were incubated at $30^{\circ} \mathrm{C}, 40^{\circ} \mathrm{C}$ and $50^{\circ} \mathrm{C}$ to determine the temperature at which cellulase is optimally produced. The CMCM and TCMCM broths (as earlier prepared), were inoculated with $5 \mathrm{ml}$ of bacterial suspensions of aerobic and anaerobic organisms respectively. Heated iron fillings were introduced into the broths for the anaerobes. Five milliliters of bacterial suspension of each isolate was then inoculated into broth submerged cultures (as labeled) and incubated separately at $30^{\circ} \mathrm{C}, 40^{\circ} \mathrm{C}$ and $50^{\circ} \mathrm{C}$ for 24 hours.

Ten milliliters $(10 \mathrm{ml})$ of broth culture at each temperature was collected in centrifuge tubes and spun for $15 \mathrm{mins}$. The supernatant (containing crude enzyme suspension) was then partially purified according to method described by Okolo (2004). The reducing sugars, protein content, $C_{1}, C_{x}$ activities and percentage loss of viscosity of carboxymethyl cellulose were determined at each temperature and recorded.

\section{Results}

Six $(50.0 \%), 4(33.3 \%)$ and $2(16.7 \%)$ of the cellulolytic bacterial organisms were obtained from the soil, rumen fluid and cowdung respectively (Table 1) cellulolytic bacterial organisms isolated from both soil and rumen content were Bacillus subtitles, Clostridium cellobioparum and Clostridium thermocellum. Pseudomonas aeruginosa was isolated from both soil and cowdung samples while Erwinia spp was obtained from both rumen content and cowdung samples. Serratia spp, Bacillus subtilis, Bacillus circulans, Clostridium cellobioparum, Clostridium thermocellum and Pseudomonas aeruginosa were obtained from soil samples only (Table 1).

Cellulase producing abilities of isolated bacterial organisms are presented in Table 2. From the highest to the lowest cellulase producers, the organisms are Clostridium thermocellum $(5.32 \mathrm{IU} / \mathrm{ml})$, Bacillus circulans $(4.80$ $\mathrm{IU} / \mathrm{ml})$, Bacillus subtilis $(4.64 \mathrm{IU} / \mathrm{ml})$, Pseudomonas aeruginosa $(3.61 \mathrm{IU} / \mathrm{ml})$, Clostridium cellobioparum $(3.17$ $\mathrm{IU} / \mathrm{ml})$, Serratia spp (1.64 IUml) and Erwinia spp (1.23 IU/ml). Total mean exoglucanase activity $(2.57 \mathrm{IU} / \mathrm{ml})$ 
was greater than total mean endoglucanase activity $(0.91 \mathrm{IU} / \mathrm{ml})$ as recorded for cellulolytic bacterial organisms. This was the reverse case for fungal organisms. Overall cellulase activity was $3.49 \pm 0.13 \mathrm{IU} / \mathrm{ml}$ with no significant difference between activities of individual organisms $(\mathrm{P}>0.05)$.

Presented in Table 3, are the reducing sugars released by cellulolytic isolates at $30^{\circ} \mathrm{C}, 37^{\circ} \mathrm{C}, 40^{\circ} \mathrm{C}$ and $50^{\circ} \mathrm{C}$ as well as at $\mathrm{pH} 3,4,5$ and 6 . All isolates at $40^{\circ} \mathrm{C}$, recorded the highest reducing sugar of $5.11 \pm 1.59 \mathrm{mg} / \mathrm{ml}$ of which Clostridium thermocellum recorded the highest $12.05 \mathrm{mg} / \mathrm{ml}$. There was however, no significant difference $(\mathrm{P}>0.05)$ among sugar yields of all isolates at $40^{\circ} \mathrm{C}$. Although the least sugar yield $(1.84 \pm 0.27 \mathrm{mg} / \mathrm{ml})$ was recorded at $30^{\circ} \mathrm{C}$ by all isolates, there was significant difference in the sugar yields obtained by the isolates at that temperature $(\mathrm{P}<0.05)$. The next highest sugar yield $(4.23 \pm 1.66 \mathrm{mg} / \mathrm{ml})$ as obtained for all isolates, was recorded at $50^{\circ} \mathrm{C}$ of which Clostridium thermocellum recorded the highest $(11.13 \mathrm{mg} / \mathrm{ml})$ yield. There was however, no significant difference in the recorded yields of sugar by the isolates $(\mathrm{P}>0.05)$. At $50^{\circ} \mathrm{C}$, Serratia spp, Pseudomonas aeruginosa and Erwinia spp recorded no sugar yield at all.

The sugar yields at varied $\mathrm{pH}$ values of 3, 4, 5 and 6 are shown also in Table 3. The bacterial isolates recorded the highest sugar yield $(3.43 \pm 0.88 \mathrm{mg} / \mathrm{ml})$ at $\mathrm{pH} 6$ followed closely by $2.94 \pm 0.48 \mathrm{mg} / \mathrm{ml}$ recorded at $\mathrm{pH} 5$. Also, Clostridium thermocellum at both $\mathrm{pH}$ values recorded the highest sugar yield. There was however no significant difference among the sugar yields as obtained by individual isolates $(\mathrm{P}>0.05)$. At $\mathrm{pH} 3$, the lowest sugar $(0.83 \pm 0.22 \mathrm{mg} / \mathrm{ml}$ yield was recorded of which Bacillus subtilis and Erwinia spp recorded the lowest yields. Pseudomonas aeruginosa recorded no sugars at all at $\mathrm{pH} 3$ even though there was a significant difference among the sugar yields at $\mathrm{pH} 3(\mathrm{P}<0.05)$.

Presented in Table 4 are the optimal $\mathrm{pH}$ and temperatures at which the isolates recorded maximum cellulolytic activities in terms of cellulolytic parameters analyzed. At pH 7.0, Serratia spp and Clostridium cellobioparum optimally recorded yields of residual sugars, exoglucanase activity $\left(\mathrm{C}_{1}\right)$, endoglcanase activity $\left(\mathrm{C}_{\mathrm{x}}\right)$, extracellular protein content and percentage loss of viscosity of carboxymethyl cellulose. Bacillus subtilis and Erwinia spp recorded the same cellulolytic activities (indices) at $\mathrm{pH}$ 6.5. Bacillus circulans and Pseudomonas aeruginosa at $\mathrm{pH} 5.5$ obtained optimal yields while Clostridium thermocellum recorded maximum yields at $\mathrm{pH}$ 6.0. All isolates are likely to obtain maximum cellulolytic activities at $\mathrm{pH} 6.29 \pm 0.9$ of which there was no significant difference in the $\mathrm{pH}$ values $(\mathrm{P}>0.05)$.

Temperature variation effect on the optimal cellulolytic activities of the isolates is also presented in Table 4. At $35^{\circ} \mathrm{C}$, Serratia spp, Bacillus subtilis and Bacillus circulans obtained optimal exoglucanase activity, endoglucanase activity, residual sugar yield, extracellular protein content and percentage loss of viscosity of carboxymethyl cellulose. Whereas $40^{\circ} \mathrm{C}$ was optimal temperature for optimal cellulolytic activities of Clostridium cellobioparum and Erwinia spp, that of Pseudomonas aeruginosa was $33^{\circ} \mathrm{C}$. Clostridium thermocellum recorded an optimum temperature of $50^{\circ} \mathrm{C}$. All isolates are likely to obtain maximum cellulolytic activities at temperature $32.6 \pm 6.19^{\circ} \mathrm{C}$ of which there was no significant difference in the temperature values $(\mathrm{P}>$ $0.05)$.

\section{Discussion}

Bacteria present an attractive potential for the exploitation of cellulases due to their rapid growth rate, enzyme complexity and extreme habitat variability (Maki et al., 2009). The high cost of cellulase production (due to use of pure chemical in production) coupled with low enzyme activities, limits its industrial use. Therefore, efforts are needed to economize cellulase production by media optimization (Kalra and Banta, 2008) and hence, isolation and characterization of cellulase producing bacteria will continue to be an important aspect of biofuel research (Hirasawa et al., 2006).

Samples used in this study included rumen liquor, cowdung and soil samples obtained from the surroundings where cowdung littered. According to Doi (2008), cellulase producing bacteria have been isolated from a wide variety of sources such as composting heaps, decaying plant material from forestry or agricultural wastes, the faeces of ruminants (cows etc). soil and organic matter.

Identified cellulase producing bacteria in this study included Serratia spp, Bacillus subtilis, Bacillus circulans, Clostridium cellobioparum, Pseudomonas aeruginosa, Erwinia spp and Clostridium thermocellum. In a similar study, Sangbrita et al. (2006) isolated Bacillus species from the intestine of tilapia and Chinese grass carp. Weng-Jing et al. (2005) isolated 15 mesophilic bacteria of which Bacillus species predominated.

Bacterial cellulase producers isolated in this study occurred in varying proportions in the sample sources examined (Table 1). Bacterial organisms isolated from cowdung were Pseudomonas aeruginosa and Erwinia spp. Pseudomonas aeruginosa (a strict aerobe) occurrence in the cowdung may be due to secondary bacterial proliferation. The inadequate and faulty observance of anaerobiosis and human error associated with media (culture media) constitution and incubation conditions may have been responsible for the rather small number of bacterial cellulase producers isolated compared to the sample size. In addition, most cellulolytic organisms are diet and location specific. Also, a very large proportion of rumen microorganisms are non-culturable rumen bacteria (Kamra, 2005). 
The highest cellulase producing bacterial isolate from this study was Clostridium thermocellum $(5.32 \mathrm{IU} / \mathrm{ml})$ followed by Bacillus circulans $(4.80 \mathrm{IU} / \mathrm{ml})$ and Bacillus subtilis $(4.64 \mathrm{IU} / \mathrm{ml})$. This is low when compared with the report of Wen-Jing et al. (2005) who isolated Bacillus cereus with maximum cellulolytic activity of 7.9 $28.0 \mathrm{IU} / \mathrm{ml}$. Maximum cellulolytic activities of $67.02 \mathrm{IU} / \mathrm{ml}$ and 35.8IU/ml as reported by Sangbriba et al. (2006) for Bacillus circulans and Bacillus megaterium respectively is also far higher than those obtained in present study. A possible explanation for the low cellulase yield in this study could be due to inadequate adherence to strict anaerobic cultural conditions for Clostridium thermocellum. Also, the first three highest cellulase producers may be different strains from those known already since cellulolytic organisms are location specific. However, Clostridium thermocellum was the highest cellulase producer in this study. According to Johnson et al. (1981), $\mathrm{Cl}$ thermocellum is noted for producing a cellulase complex known as cellulosome which has a very high cellulolytic activity. Cellulosome eliminates the wasteful expenditure of microorganisms thus continuously producing copious amounts of free cellulases (Shoham, 1999).

A high accumulation of sugar is a clear manifestation of high enzyme production and activity (Ejechi, 1991). Glucose is one of the main products of cellulose breakdown (Bisaria and Ghose, 1981; Okolo, 2004). If cellulose containing wastes were to be used as substrates, the waste problem would be solved (Coombs, 1987). Glucose can be fermented to form ethanol which can be used as fuel. Ethanol can be dehydrated to produce ethylene - a major compound used in the chemical industries. Glucose (sugar) also has uses in the pharmaceutical, food and bioscience based industries (Coombs, 1987)

Although, statistically, there was no significant difference in residual sugar of all isolates (accumulated sugar in culture broth) as obtained by bacterial isolates at pH6 ( $>0.05)$, the highest sugar yield $(3.43 \pm 0.88 \mathrm{mg} / \mathrm{ml}) \mathrm{was}$ recorded at that $\mathrm{pH}$. At $40^{\circ} \mathrm{C}$, all isolates obtained the maximum sugar accumulation $(5.11 \pm 1.59 \mathrm{mg} / \mathrm{ml})$ in broth culture. There was however no significant difference among individual yields $(\mathrm{P}>0.05)$. It appears therefore, that optimal temperature and $\mathrm{pH}$ for optimal residual sugar yield by cellulolytic bacteria in our environment are $40^{\circ} \mathrm{C}$ and 6 if all other submerged cultural conditions are maintained. At the other extreme, a temperature and $\mathrm{pH}$ of $30^{\circ} \mathrm{C}$ and 3 respectively may inhibit sugar accumulation in culture broth. This was shown by Pseudomonas aeruginosa which recorded total absence of sugar at $30^{\circ} \mathrm{C}$ and $\mathrm{pH}$ and 3 . Also within these cultural conditions, Bacillus subtilis and Erwinia spp recorded less than $1.00 \mathrm{mg} / \mathrm{ml}$. The lowest accumulated broth sugar yields of $(1.83 \pm 0.27 \mathrm{mg} / \mathrm{ml}$ and $0.83 \pm 0.22 \mathrm{mg} / \mathrm{ml})$ were obtained at $30^{\circ} \mathrm{C}$ and $\mathrm{pH} 3$ respectively.

Cellulolytic activities (indices) of all bacterial isolates peaked at $38.6 \pm 0.19^{\circ} \mathrm{C}$ and $\mathrm{pH} 6.29 \pm 0.94$ although there was no significant difference among the individual values recorded $(\mathrm{P}>0.05)$. At $\mathrm{pH} 7.0$, Serratia $\mathrm{spp}$ and Clostridium cellobioparum recorded optimal yields of residual sugars, exoglucanase activity, extracellular protein content and percentage loss of viscosity of carboxymethyl cellulose.

At $35^{\circ} \mathrm{C}$, Serratia spp, Bacillus subtilis and Bacillus circulans recorded optimal cellulolytic activities. At pH 5 and $35^{\circ} \mathrm{C}$, Bacillus subtilis recorded optimal yield of residual sugar, endoglucancase and exoglucanase activities. This differed from the finding of Immanuel et al. (2006) who recorded $40^{\circ} \mathrm{C}$ and $\mathrm{pH} 7$ as optimal for endoglucanase activity of Bacillus spp. Also different, were the reports of Li et al. (2008) and Hirosawa et al. (2006) who recorded $50^{\circ} \mathrm{C}$ and $\mathrm{pH} 7$ as optimal for cellulase production by Bacillus subtilis and Bacillus agaradherens JAM-Ku-23.

Bacillus circulans at $\mathrm{pH} 4$ and $35^{\circ} \mathrm{C}$, recorded optimal residual sugar yield. At $\mathrm{pH}$ 6, maximum exoglucanase activity and percentage loss of viscosity of CM-cellulose were also recorded for Bacillus circulans at $35^{\circ} \mathrm{C}$. Finding in this study differed from that of Sangbriba et al. (2006), who recorded maximum cellulolytic activities of Bacillus circulans and B. megaterium at $30^{\circ} \mathrm{C}$ and $\mathrm{pH}$. Ariffin et al. (2008) reported optimal endoglucanase activity of Bacillus pumulus $\mathrm{EB} 3$ at $37^{\circ} \mathrm{C}$ and $\mathrm{pH} 7$ which is also different from findings in present study. Clostridium thermocellum however attained optimal cellulolytic activities at $50^{\circ} \mathrm{C}$ and $\mathrm{pH}$ 6. Perez-Avalos et al. (2008) worked with Cellulomonas flavigena and recorded $55^{\circ} \mathrm{C}$ and $\mathrm{pH} 6$ as optimal for its cellulolytic activities. This finding is similar to that recorded for $\mathrm{Cl}$. thermocellum in present study.

Findings in this study did not exactly agree with those of other authors as cited and the reason may not be far fetched. Most of the studies cited were carried out in other parts of the world especially in the temperate regions. Cellulolytic organisms by virtue of habitat or source, are location and diet specific. Hence findings are peculiar to our environment. This however, is not to say that findings are fool-proof owing to cultural and equipment efficiency challenges encountered in the course of prosecuting the research.

Though the total cellulase yield of $3.49 \pm 0.13 \mathrm{IU} / \mathrm{ml}$ is much lower than commercial cellulase, it can be used in its crude and partially purified forms but at high ratios, to saccharify pretreated wastes first to sugars, then ethanol, ethylene, methane and biogas. Also, since all isolates attained maximum cellulolytic activities at $32.6 \pm$ $6.19^{\circ} \mathrm{C}$ and $\mathrm{pH} 6.29 \pm 0.94$, the problem of high cost of cellulase production owing to low enzyme activities of organisms used industrially for its production can be solved by meticulously observing the optimal cultural growth conditions reported in this study. 


\section{Conclusion}

Cellulolytic bacterial organisms isolated included Serratia spp, Bacillus subtilis, Bacillus circulans, Clostridium cellobioparum, Pseudomonas aeruginosa, Erwinia spp and Clostridium thermocellum of which Bacillus subtilis, Clostridium cellobioparum and Clostridium thermocellum were isolated from soil and rumen fluid. Whereas Pseudomonas aeruginosa was isolated from both soil and cowdung samples, Erwinia spp was isolated from both rumen fluid and cowdung samples.

From highest to the lowest cellulase concentrations, Clostridium thermocellum produced the highest yield of cellulase in culture broth while Erwinia spp produced the least. All isolates at $40^{\circ} \mathrm{C}$ and $\mathrm{pH}$ 6, recorded optimal residual sugars in culture broth of which Clostridium thermocellum had the highest yield. There was however, no significant difference $(\mathrm{P}>0.05)$ among sugar yields for all isolates at $40^{\circ} \mathrm{C}$ and $\mathrm{pH}$. The lowest yields were recorded at $30^{\circ} \mathrm{C}$ and $\mathrm{pH} 3$ although there was significant difference in individual yields $(\mathrm{P}<0.05)$. At 50 $\mathrm{C}$ and pH 3, Serratia spp, Pseudomonas aeruginosa and Erwinia spp recorded no sugar yield in culture broth.

Serratia spp and Clostridium cellobioparum however at $\mathrm{pH} 7$ and $40^{\circ} \mathrm{C}$, recorded optimal cellulolytic activities in terms of residual sugars, exoglucanase activity, endoglucanase activity, extracellular protein content and percentage loss of viscosity of carboxymethyl cellulose. Bacillus circulans and Pseudomonas aeruginosa recorded similar cellulolytic activities at $\mathrm{pH} 5.5$ but at varying temperatures of $35^{\circ} \mathrm{C}$ and $40^{\circ} \mathrm{C}$ respectively. Clostridium thermocellum recorded maximum cellulolytic activities at $50^{\circ} \mathrm{C}$ and $\mathrm{pH} 6$.

All isolates are likely to attain optimal cellulolytic activities at $32.6 \pm 6.2^{0} \mathrm{C}$ and $\mathrm{pH} 6.3 \pm 0.9$ if other broth cultural conditions are kept constant. Though the total cellulase yield of $3.49 \pm 0.1 \mathrm{IU} / \mathrm{ml}$ is much lower than commercial cellulase, it can be used in its crude or partially purified form but at higher ratios, to saccharify pretreated wastes first to sugars, then ethanol, ethylene, methane and biogas. Also, since all isolates attained maximum cellulolytic activities at $32.6 \pm 6.2^{\circ} \mathrm{C}$ and $\mathrm{pH} 6.29 \pm 0.9$, the problem of high cost of cellulase production and biogas (owing to low enzyme activities of organisms used industrially for their production) can be solved by meticulously observing the optimal cultural growth conditions reported in this study.

\section{References}

Ariffin, H., Hassan, M.A., Shah, U.K., Abdullah, N., Ghazali, F.M and Shirai, Y. (2008). Production of Bacterial Endoglucanase from Pretreated Oil Palm empty fruit bunch by Bacillus pumilus EB3. Journal of Bioscience and Bioengineering. 106 (3): 231 - 236.

Bassey, E.B. (2002). Utilisation of Microbial Isolates in the management of Cellulosic Health Care Wastes in the Federal Capital Territory, Abuja. Ph.D thesis, University of Benin. 243p.

Bisaria, V.S and Ghose, T.K. (1981). Biodegradation of cellulose Materials: Substates, Microorganisms, Enzymes \& Products. Enzyme Microbial Technol. 3: 90 - 104.

Coral, G., Arikan, B and Unaldi, M.N. (2002). Some properties of crude carboxymet thyl cellulose of Aspergillus niger wild type strain. Turk J. Biol. 26: 209-213.

Cowan, S. T and Steel, K.J. (1993). Manual for the identification of medical bacteria $3^{\text {rd }}$ edn. Cambridge University press. $150 \mathrm{p}$.

Cullimore, D.R. (2000). Practical Atlas for Bacterial Identification. Lewis Publishers, Boca Raton, London, New York. 209p.

Deumas, R., Tengerdy, R.P and Qutierrez-Correal, J. (1995). Cellulase production by mixed fungi in solid substrate fermentation of bagasse. World J. Microbiol. Biotech. 11: 333 - 337.

Dhawan, S and Gupta, J.K. (1977). Enzymatic hydrolysis of common cellulosic wastes by cellulase. J. Gen and Appl. Microbiol. 23: 155 - 166.

Doi, R.H. (2008). Cellulase of mesophilic microbes: cellulosome and non-cellulosome producers. Ann. NY. Acad. Sci. 1125: $267-279$.

Ejechi, B. O. (1991). Biodegradation of some Nigerian Timbers by fungi. Ph.D thesis. 499p.

Griffin, H.L., Sloneker, J.H and Inglett, G.E. (1974). Cellulose production by Trichoderma viridae on feedlot waste. Appl. Microbiol. 27: 1061 - 1066.

Hirasawa, K., Uchimura, K., Kashima, M., Grant, W.D., Ito, S., Kobayashi, T and Horikoshi, K. (2006). Salt activated endoglucanase of a strain of alkaliphilic Bacillus agaradhaerens. Antonie Van Leuwenhoek. 89 (2): 211 -219 .

Immanuel, G., Dhanusa, R., Prema, P and Palavesa, A. (2006). Effects of different growth parameters on endoglucanase enzyme activity by bacteria isolated from coir retting effluents of estuarine environment. Int. $J$. Envir. Sci. Techn. 3(1): $25-34$.

Johnson, E.A., Madia, A and Demain, A.L. (1981). Chemically defined minimal medium for the growth of the anaerobic cellulolytic thermophile - Clostridium thermocellum. Appl. Environ. Microbiol. 41: 1060 - 1062. 
Juhasz, T., Szengyel, Z., Szijarrto, N and Reezey, K. (2004). Effect of pH on cellulase production of Trichoderma reesei RUT C30. Biotechnology. 113: $201-212$.

Kalra, K.L., Kocher, G and Banta, G. (2008). Optimization of cellulose production by submerged fermentation of rice straw by Trichoderma harzianum RUT-C. 8230. The Internet Journal of Microbiology. 5(2): 1 - 7.

Kamra, D.N. (2005). Rumen microbial ecosystem. Microbiology section, centre of advanced studies. In Animal nutrition. Indian Veterinary Research Institute. 89(1): 243 - 246.

Ko, C.H., Chen, W.L., Tsai, C.H., Jane, W.N., Liu, C.C and Tu, J. (2007). Paenibacillus campinasensis BL11: a wood material-utilizing bacterial strain isolated from black liquor. Bioresource Technol. 14: 2727 - 2733.

Li, W., Zhang, W.W., Yang, M.M and Chen, Y.L. (2008). Cloning of the thermostable cellulase gene from newly isolated Bacillus subtilis and its expression in Escherichia coli. Mol. Biotechnol. 2: $195-201$.

Lowry, O. H., Rosebrough, N. J., Farr, A. L and Randall, R. (1951). Protein measurement with the folin phenol reagent. Journal of biology \& chemistry. 193: $265-275$.

Mackenzie, C. R., Patel, G. B and Bilous, D. (1987). Factors involved in hydrolysis of microcrystalline cellulose by Acetivibrio cellulolyticus. Appl. Environ. Microb. 53: 304 - 308.

Maki, M., Leung, K.T and Quin,W. (2009).The prospect of cellulase producing bacteriafor bioconversion of lignocellulosic biomass. Int. J. Bio. Sci. 5: $500-516$.

Miller, G. L. (1972). Use of dinitrosalicylic acid reagent for determination of reducing sugar. Biotechnol. Bioeng. Sympo. 5: $193-219$.

Munro, A. L. S. (1970). Measurement and control of pH in J.R. Norris \& D. W. Ribbons (editors) Methods in Microbiology. Academic press. Pp75 - 89.

Norkrans, B and Hammarstrom, K. (1963). Studies on growth of Rhizina undulate and its production of cellulase and pectin decomposing enzymes. 16: $1-10$.

Okolo, J.C. (2004). Cellulose hydrolysis by partially purified enzymes of Paeciolmyces species. Nigerian Journal of Microbiology. 18(2): 293 - 296.

Okoth, S.A., Rolmen, H., Mutsotso, B and Owino, J.O. (2007). Land Use systems and Distribution of Trichoderma species in Embu Region, Kenya. Journal of Tropical and Subtropical Agrosystems 7: 105 - 122.

Pei-Jun, L.I., De-Bing, Z., Qui-xing and Chun-gui, Z. (2004). Optimization of solid fermentation of cellulase from Trichoderma koningii. L. Envron. Sci. 6: 816-820

Perez-Avalos, O., Sanchez-Herrera, L.M and Ponce-Noyola, T. (2008). A bifunctional endoglucanase/endoxylanase from Cellulomonas flavigena with potential use in indusrial processes at different pH. Curr. Microbiol. 57 (1): $39-44$.

Ray, A.K., Bairagi, K.S, Ghosh, A and Sen, S.K. (2007). Optimization of fermentation conditions for cellulase production by Bacillus subtilis CY5 and Bacillus circulans TP3 isolated from fish gut. Acat. Icht. Et. Pist. 37: 47 $-53$.

Sangbriba, R.U, Duan, C.J and Tang, J.L. (2006). Isolation and characterization of mesophilic Bacillus species cellulase genes from black liquor. Bioresour. Technol. 14: 2727 - 2733.

Shoham, Y., Lamed, R and Bayer, E.A. (1999). The cellulosome concept as an efficient microbial strategy for the degradation of insoluble polysaccharides. Trends Microbiol. 7 (7): 275 - 281.

Solomon, B.O., Amigun, B., Betikue, TU.V, Ojumu, T and Layokun, S.K. (1999). Optimization of cellulase production by Aspergillus flavus Linn. Isolates NSPR 101 grown on baggase. JNSCHE. 18: $61-68$.

Wang, C.M., Shyu, C.L and Ho, S.P. (2008). Characterization of a novel thermophilic cellulose degrading bacterium - Paenibacillus spp strain B39. Lett. Appl. Microbiol. 47: 46 - 53.

Wen - Jing, L. U., Hong - Tao, W., Shi - Jian, Y., Zhi - Chao, W and Young Feng, N. (2005). Isolation and characterization of mesophilic cellulose - degrading bacteria from flower stalk vegetable waste composting system. Journal of General and Applied Microbiology. 51(6): 353 - 360

Zaldivar, M., Velasquez, J.C and Contreras - Perez, L.M. (2001). Trichoderma aureovi aureoviride 7 - 121, a mutant with enhanced production of lytic enzymes: its potential use in waste cellulose degradation. Journal of Biotech. 4(3): pp1 - 6 . 
Table 1. Sample Site Distribution of Cellulolytic Bacterial Organisms

\begin{tabular}{|l|c|c|c|}
\hline Identified Bacterial Organisms & Soil & Rumen fluid & Cowdung \\
\hline Serratia spp & + & - & - \\
\hline Bacillus subtilis & + & + & - \\
\hline Bacillus circulans & + & + & - \\
\hline Clostridium cellobioparum & + & + & - \\
\hline Pseudomonas aeruginosa & + & - & + \\
\hline Erwinia spp & - & + & + \\
\hline Clostridium thermocellum & + & + & - \\
\hline Total: $\mathbf{1 2 ( 1 0 0 . 0 \% )}$ & $\mathbf{6 ( 5 0 . 0 \% )}$ & $\mathbf{4 ( 3 3 . 3 \% )}$ & $\mathbf{2 ( 1 6 . 7 \% )}$ \\
\hline
\end{tabular}

Table 2. Cellulase Production by Cellulolytic Bacterial Organisms at $37^{\circ} \mathrm{C}, \mathrm{pH} 7.2$

\begin{tabular}{|l|c|c|c|}
\hline Cellulolytic Bacterial Organisms & $\mathbf{C}_{\mathbf{1}}(\mathbf{I U} / \mathbf{m l})$ & $\mathbf{C}_{\mathbf{X}}(\mathbf{I U} / \mathbf{m l})$ & Total Cellulase Activity (IU/ml) \\
\hline Serratia spp & 0.89 & 0.75 & 1.64 \\
\hline Bacillus subtilis & 4.06 & 0.58 & 4.64 \\
\hline Bacillus circulans & 3.46 & 1.34 & 4.80 \\
\hline Clostridium cellobioparum & 1.18 & 1.99 & 3.17 \\
\hline Pseudomonas aeruginosa & 3.16 & 0.45 & 3.61 \\
\hline Erwinia spp & 0.90 & 0.33 & 1.23 \\
\hline Clostridium thermocellum & 4.36 & 0.90 & 5.32 \\
\hline Mean: & $\mathbf{2 . 5 7}$ & $\mathbf{0 . 9 1}$ & Mean \pm S.E: 3.49 $\pm \mathbf{0 . 1 3}$ \\
\hline & $\mathbf{( P > 0 . 0 5 )}$ \\
& $\mathbf{C}_{\mathbf{1}}=$ Exoglucanase Activity \\
$\mathbf{C}_{\mathbf{X}}=$ Endoglucanase Activity
\end{tabular}

Table 3. Residual Sugars Released by Cellulolytic Bacterial Organisms at $30^{\circ} \mathrm{C}, 37^{\circ} \mathrm{C}, 40^{\circ} \mathrm{C}, 50^{\circ} \mathrm{C}$ and $\mathrm{pH} 3,4,5$, 6

\begin{tabular}{|c|c|c|c|c|c|}
\hline $\begin{array}{c}\text { Cellulolytic Bacter } \\
\text { Organisms }\end{array}$ & $\begin{array}{r}\text { rial Temp } \\
\text { pH: }\end{array}$ & $\begin{array}{c}30^{\circ} \mathrm{C} \\
3 \\
(\mathrm{IU} / \mathrm{ml})\end{array}$ & $\begin{array}{c}37^{\circ} \mathrm{C} \\
4 \\
(\mathrm{IU} / \mathrm{ml})\end{array}$ & $\begin{array}{c}40^{\circ} \mathrm{C} \\
5 \\
(\mathrm{IU} / \mathrm{ml})\end{array}$ & $\begin{array}{c}50^{\circ} \mathrm{C} \\
6 \\
(\mathrm{IU} / \mathrm{ml})\end{array}$ \\
\hline Serratia spp & $\begin{array}{c}\text { Temp } \\
\mathrm{pH}\end{array}$ & $\begin{array}{l}1.01 \\
1.55\end{array}$ & $\begin{array}{l}1.83 \\
0.52\end{array}$ & $\begin{array}{l}0.90 \\
2.00\end{array}$ & $\begin{array}{l}0.00 \\
1.71\end{array}$ \\
\hline Bacillus subtilis & $»$ & $\begin{array}{l}1.40 \\
0.99\end{array}$ & $\begin{array}{l}4.88 \\
1.64\end{array}$ & $\begin{array}{l}6.03 \\
4.01\end{array}$ & $\begin{array}{l}5.60 \\
2.55\end{array}$ \\
\hline Bacillus circulans & & $\begin{array}{l}1.46 \\
1.08\end{array}$ & $\begin{array}{l}4.58 \\
2.91\end{array}$ & $\begin{array}{l}5.60 \\
4.11\end{array}$ & $\begin{array}{l}5.10 \\
1.34\end{array}$ \\
\hline Clostridium cellobi & bioparum & 2.52 & 4.03 & 8.13 & 7.77 \\
\hline & 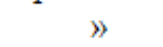 & 1.04 & 1.11 & 3.21 & 4.50 \\
\hline Pseudomonas aeru & uginosa & $\begin{array}{c}1.62 \\
0.00\end{array}$ & $\begin{array}{l}3.53 \\
2.60\end{array}$ & $\begin{array}{c}3.05 \\
1.05\end{array}$ & $\begin{array}{c}0.00 \\
3.03\end{array}$ \\
\hline Enwinia spp & $»$ & $\begin{array}{c}1.80 \\
0.08\end{array}$ & $\begin{array}{c}1.66 \\
0.93\end{array}$ & $\begin{array}{l}0.04 \\
2.01\end{array}$ & $\begin{array}{l}0.00 \\
2.65\end{array}$ \\
\hline Clostridium thermoc & $\begin{array}{r}\text { cellum } \\
\text { " }\end{array}$ & $\begin{array}{c}3.09 \\
1.10\end{array}$ & $\begin{array}{l}5.95 \\
1.44\end{array}$ & $\begin{array}{l}12.05 \\
4.21\end{array}$ & $\begin{array}{l}11.13 \\
8.21\end{array}$ \\
\hline $\begin{array}{l}\text { Mean } \pm \text { S.E } \\
\text { Mean } \pm \text { S.E } \\
\text { P value } \\
\text { P value }\end{array}$ & $\begin{array}{l}\text { Temp } \\
\text { pH } \\
\text { Temp } \\
\text { pH }\end{array}$ & $\begin{array}{l}1.84 \pm 0.27 \\
0.83 \pm 0.22 \\
P<0.05 \\
P<0.05\end{array}$ & $\begin{array}{l}3.78 \pm 1.03 \\
1.59 \pm 0.33 \\
P>0.05 \\
P<0.05\end{array}$ & $\begin{array}{l}5.11 \pm 1.59 \\
2.94 \pm 0.48 \\
P>0.05 \\
P>0.05\end{array}$ & $\begin{array}{l}4.23 \pm 1.66 \\
3.43 \pm 0.88 \\
P>0.05 \\
P>0.05\end{array}$ \\
\hline
\end{tabular}


Table 4. Optimal Temperature and $\mathrm{pH}$ Conditions for Optimal Cellulolytic Activities by Bacterial Organisms

\begin{tabular}{|c|c|c|c|c|}
\hline $\begin{array}{l}\text { Cellulolytic Bacterial } \\
\text { Organisms }\end{array}$ & $\begin{array}{l}\text { Optimal pH } \\
\text { \& Cellulolytic } \\
\text { Activities }\end{array}$ & $\begin{array}{l}\text { Optimal } \\
\text { pH Range } \\
\text { (mean) }\end{array}$ & $\begin{array}{l}\text { Optimal Temp. } \\
\text { \& Cellulolytic } \\
\text { Activities }\end{array}$ & \multirow[t]{2}{*}{$\begin{array}{l}\text { Optimal Temp. } \\
\text { Range (mean) }\end{array}$} \\
\hline Serratiaspp & $\begin{array}{l}6\left(\text { Sug, } C_{1} C_{x}\right) \\
8 \text { (Prot, Visc) }\end{array}$ & $\begin{array}{l}6-8 \\
(7.0)\end{array}$ & $\begin{array}{l}30^{\circ} \mathrm{C} \text { (Sug,Prot, } \mathrm{C}_{1}, \mathrm{C}_{\mathrm{x}} \text { ) } \\
40^{\circ} \mathrm{C} \text { (Visc.) }\end{array}$ & \\
\hline Bacillus subtilis & $\begin{array}{l}\left.5 \text { (Prot, } C_{\mathrm{x}}\right) \\
8\left(\mathrm{C}_{1}, \text { Sug, Visc }\right)\end{array}$ & $\begin{array}{l}5-8 \\
(6.5)\end{array}$ & $\begin{array}{l}30^{\circ} \mathrm{C}\left(\text { Sug,Prot, } \mathrm{C}_{\mathrm{x}}\right) \\
37^{\circ} \mathrm{C}\left(\mathrm{C}_{1}\right), 40^{\circ} \mathrm{C}\left(\mathrm{Visc}_{1 \mathrm{c}}\right)\end{array}$ & $\begin{array}{c}30^{\circ} \mathrm{C}-40^{\circ} \mathrm{C} \\
\left(35^{\circ} \mathrm{C}\right)\end{array}$ \\
\hline Bacillus circulans & $\begin{array}{l}4 \text { (Sug), } 6\left(\mathrm{C}_{1}, \text { Visc }\right) \\
7 \text { (Cx,Prot) }\end{array}$ & $\begin{array}{l}4-7 \\
(5.5)\end{array}$ & $\begin{array}{l}37^{\circ} \mathrm{C}\left(\mathrm{C}_{1}, \mathrm{Visc}_{1}, 30^{\circ} \mathrm{C}\right. \\
\text { (Prot), } 40^{\circ} \mathrm{C}\left(\mathrm{Sug}_{\mathrm{g}} \mathrm{C}_{\mathrm{x}}\right)\end{array}$ & $\begin{array}{c}30^{\circ} \mathrm{C}-40^{\circ} \mathrm{C} \\
\left(35^{\circ} \mathrm{C}\right)\end{array}$ \\
\hline Clostridium cellobioparum & $\begin{array}{l}\text { 7(Prot, } \mathrm{Cx},), 6 \\
\left.\text { (Visc),8(Sug, } \mathrm{C}_{1}\right)\end{array}$ & $\begin{array}{l}6-8 \\
(7.0)\end{array}$ & $\begin{array}{c}\left.30^{\circ} \mathrm{C} \text { (Sug,Prot, } \mathrm{C}_{1}\right) \\
40^{\circ} \mathrm{C} \text { (Visc), } 50^{\circ} \mathrm{C}\left(\mathrm{C}_{\mathrm{x}}\right)\end{array}$ & $\begin{array}{l}30^{\circ} \mathrm{C}-50^{\circ} \mathrm{C} \\
\left(40^{\circ} \mathrm{C}\right)\end{array}$ \\
\hline Pseudomonas aeruginosa & $\begin{array}{c}\left.a \quad \text { (Sug, } \mathrm{C}_{1}, \mathrm{C}_{\mathrm{x}}, \text { Prot }\right) \\
7 \text { (Visc) }\end{array}$ & $\begin{array}{r}4-7 \\
(5.5)\end{array}$ & $\begin{array}{c}30^{\circ} \mathrm{C}\left(\text { Sug,Prot, } \mathrm{C}_{\mathrm{x}}\right) \\
37^{\circ} \mathrm{C}\left(\text { Visc }_{2} \mathrm{C}_{1}\right)\end{array}$ & $\begin{array}{r}30^{\circ} \mathrm{C}-37^{\circ} \mathrm{C} \\
\left(33^{\circ} \mathrm{C}\right\}\end{array}$ \\
\hline Erwinia spp & $\begin{array}{l}6\left(\mathrm{C}_{1}, \mathrm{C}_{\mathrm{x}}, \mathrm{Visc}\right) \\
7 \text { (Sug,Prot) }\end{array}$ & $6-7(6.5)$ & $\begin{array}{l}\left.30^{\circ} \mathrm{C} \text { (Sug, Prot, } \mathrm{C}_{1}\right) \\
\quad 40^{\circ} \mathrm{C} \text { (Visc) }, 50^{\circ} \mathrm{C}\left(\mathrm{C}_{\mathrm{x}}\right)\end{array}$ & $\begin{array}{l}30^{\circ} \mathrm{C}-37^{\circ} \mathrm{C} \\
\left(40^{\circ} \mathrm{C}\right)\end{array}$ \\
\hline \multirow[t]{2}{*}{ Clostridium thermocellum } & $\begin{array}{l}\text { 6.5(Sug,Prot) } \\
\text { 5(C1),7(Cx,Visc) }\end{array}$ & $\begin{array}{l}5-7 \\
(6.0)\end{array}$ & $\begin{array}{l}60^{\circ} \mathrm{C}\left(\text { Prot, } \mathrm{C}_{1}, \mathrm{C}_{\mathrm{x}}\right) \\
50^{\circ} \mathrm{C}(\text { Sug }), 40^{\circ} \mathrm{C}\left(\mathrm{C}_{\mathrm{x}}\right)\end{array}$ & $\begin{array}{c}40^{\circ} \mathrm{C}-60^{\circ} \mathrm{C} \\
\left(50^{\circ} \mathrm{C}\right)\end{array}$ \\
\hline & Mean \pm S.E: & $\begin{array}{l}5.29 \pm 0.94 \\
p>0.05\end{array}$ & & $\begin{array}{l}38.6 \pm 0.19 \\
>0.05\end{array}$ \\
\hline
\end{tabular}

Sug - Residual sugar

$\mathrm{C}_{1}$ - Exoglucanase activity

$\mathrm{Cx}$ - Endoglucanase (Carboxylmethyl cellulase) activity

Prot - Extracellular protein content

Visc - Percentage loss of viscosity of carboxyl methyl cellulose 